\title{
Jurist-Diction
}

Volume 4 No. 1, Januari 2021

\section{Akibat Hukum Keberlakuan Peraturan Pemerintah Nomor 49 Tahun 2018 Tentang Manajemen Pegawai Pemerintah Dengan Perjanjian Kerja Terhadap Pengangkatan Pegawai Komisi Pemberantasan Korupsi Yang Belum Berstatus Pegawai Aparatur Sipil Negara}

\section{Muhammad Junaidi Fitriawan Trisnanda}

Ryan9fitriawan@gmail.com

Universitas Airlangga

How to cite:

Muhammad Junaidi Fitriawan Trisnanda, 'Akibat Hukum Keberlakuan Peraturan Pemerintah Nomor 49 Tahun 2018 Tentang Manajemen Pegawai Pemerintah Dengan Perjanjian Kerja Terhadap Pengangkatan Pegawai Komis Pemberantasan Korupsi Yang Belum Berstatus Pegawai Aparatur Sipil Negara' (2021) Vol. 4 No. 1 Jurist-Diction.

Histori artikel:

Submit 1 Oktober 2020; Diterima 12 November 2020; Diterbitkan 5 Januari 2021.

DOI:

10.20473/jd.v4i1.24300

p-ISSN: 2721-8392 e-ISSN: $2655-8297$

\section{Abstract}

Consequence of KPK's Law revision that mention KPK employment must be State Civil Apparatus (ASN) previously not required to be ASN. Indirectly, change employee mechanism in KPK. This change, will effect government regulation 2018 number 49 that in Article 96 pargraph (1) forbid staffing officer (PPK) to place Non-ASN employee to fill ASN position. That will create employee dispute between older KPK employee and KPK after KPK's Law revision entry into force. Then, required effort to resolve that employee dispute to protect older $K P K$ employee from disadvantage that can appear to KPK employee that have not ASN. That effort such as administrative effort consist of objection and administrative appeal, and submit a claim to Civil Court of Justice, etc. Thus, that loss KPK employee able to get legal protection in defend their employee right that have been lost when $K P K$ 's Law revision that mention KPK employment must be ASN entry into force.

Keywords: State Civil Apparatus; Komisi Pemberantasan Korupsi; Legal Protection.
Abstrak
Perubahan yang terjadi dalam status kepegawaian Komisi Pemberantasan Korupsi (KPK) akibat adanya revisi undang-undang KPK yang menyebutkan bahwa Pegawai KPK harus merupakan Pegawai Aparatur Sipil Negara (ASN) yang sebelumnya tidak wajib merupakan Pegawai ASN. Secara tidak langsung terjadi perubahan dalam mekanisme kepegawaian di KPK. Perubahan ini, akan berdampak berlakunya Peraturan Pemerintah Nomor 49 Tahun 2018 yang dalam pasal 96 ayat (1) melarang Pejabat Pembina Kepegawaian (PPK) untuk menempatkan Pegawai Non-ASN untuk menempati jabatan ASN. Sehingga dapat menimbulkan sengketa antara Pegawai KPK yang lama dengan KPK setelah diberlakukannya revisi undang- undang KPK. Maka diperlukannya upaya untuk menyelesaikan sengketa kepegawaian tersebut untuk melindungi Pegawai lama KPK dari kerugian yang dapat timbul kepada Pegawai KPK yang belum ASN. Diantaranya melalui upaya administratif yang terdiri dari upaya keberatan dan banding administratif, kemudian pengajuan gugatan kepada Pegadilan Tata Usaha Negara dan upaya hukum lainnya yang 
dapat ditempuh. Sehingga Pegawai KPK yang dirugikan tersebut
mampu mendapatkan perlindungan hukum dalam mempertahankan
hak kepegawaiannya yang telah hilang akibat keberlakuan Revisi
Undang-undang KPK yang mewajibkan Pegawai KPK adalah Pegawai
ASN mulai berlaku.
Kata Kunci: Aparatur Sipil Negara; Komisi Pemberantasan Korupsi;
Perlindungan Hukum.

Copyright $\odot 2021$ Universitas Airlangga

\section{Pendahuluan}

Pegawai merupakan suatu bagian yang penting dalam suatu sistem yang memanfaatkan sumber daya manusia dalam suatu sistem kerja yang saling melengkapi satu sama lain dalam mencapai suatu tujuan. ${ }^{1}$ Berdasarkan hal ini kepegawaian merupakan bagian yang penting terutama dalam pemerintahan yang menjalankan fungsi negara untuk memberikan pelayanan yang terbaik kepada masyarakat sebagai tujuan yang hendak dicapai negara dalam melayani rakyat. ${ }^{2}$ Oleh karena itu, pemerintahan tidak terlepas dari adanya hubungan dengan kepegawaian.

Dalam upaya mewujudkan tujuan negara salah satunya memajukan kesejahteraan umum, yang mana nilai-nilainya bertentangan dengan kesejahteraan individu dengan perbuatan melanggar hukum salah satunya dengan melakukan perbuatan korupsi maka perlu ada penegakan hukum dalam perbuatan tersebut. Walaupun telah berdiri lembaga-lembaga penegak hukum seperti kepolisian dan kejaksaan namun tingkat kepuasan masyarakat Indonesia terhadap upaya penegakan hukum terhadap perbuatan korupsi tersebut masihlah kurang sehingga pemerintah melakukan upaya maksimal dengan membentuk lembaga tersendiri dengan program kerja yang lebih spesifik untuk menangani tindak pidana korupsi yaitu lembaga Komisi Pemberantasan Korupsi yang mana menjalankan perintah Undangundang Nomor 31 Tahun 1999 tentang Pemberantasan Tindak Pidana Korupsi (UU Tipikor) Pasal 43 yang memuat norma perintah pembentukan lembaga khusus untuk menjalankan UU Tipikor yang kemudian menjadi cikal bakal berdirinya lembaga pemberantasan korupsi yaitu Komisi Pemberantasan Korupsi (KPK)

1 Putu Ayu Mitha Ananda Putri, dan I Gede Yusa, 'Peranan Pegawai Negeri Sipil Dalam Penyelenggaraanpelayanan Terpadu Satu Pintu' (2016) 1(1) Jurnal Universitas Udayana.[2].

2 ibid.[3]. 
yang didasarkan pada Undang-Undang Nomor 30 tahun 2002 tentang Komisi Pemberantasan Tindak Pidana Korupsi (UU KPK).

Pada 6 September 2019, tepat sebelum masa pengabdian Dewan Perwakilan Rakyat periode 2014-2019 berakhir dan untuk menunjukkan hasil kinerja selama periodenya, maka disahkan Undang-Undang Nomor 19 Tahun 2019 tentang Perubahan Kedua Atas Undang-Undang Nomor 30 Tahun 2002 tentang Komisi Pemberantasan Tindak Pidana Korupsi (Revisi UU KPK) yang berisi revisi dari hal-hal yang perlu diterapkan pada KPK. ${ }^{3}$ Salah satu hasil yang direvisi adalah mengenai kedudukan dari KPK yang sebelumnya merupakan lembaga negara yang bersifat independen terbatas yang tidak terhubung langsung dengan kekuasaan negara untuk menjalankan fungsinya kemudian berdasarkan Pasal 1 angka 3 Revisi UU KPK menjadi lembaga negara yang berada dalam rumpun kekuasaan eksekutif. Dengan perubahan kedudukan ini, maka manajemen kepegawaian dalam lembaga KPK ikut berubah untuk menyesuaikan dengan peraturan perundang-undangan yang berlaku. Dalam hal kepegawaian berdasarkan peraturan perundang-undangan yang berlaku diatur dalam UU ASN yang salah satunya memberikan batasan terhadap jenis-jenis pegawai ASN pada Pasal 6 UU ASN yaitu PNS, dan PPPK. Maka lembaga KPK harus menyesuaikan mengenai kepegawaiannya menurut UU ASN yaitu pegawai dalam KPK merupakan Pegawai ASN sesuai UU ASN yang dalam hal ini telah diatur berdasarkan Pasal 1 angka 6 jo. Pasal 24 ayat (2) Revisi UU KPK. Untuk melaksanakan ketentuan tersebut, berdasarkan Pasal 69C KPK diberikan jangka waktu paling lama 2(dua) tahun terhitung sejak Revisi UU KPK berlaku kepada pegawai KPK yang belum berstatus Pegawai ASN dapat diangkat menjadi Pegawai ASN sesuai perundang-undangan. Selain itu, karena KPK merupakan lembaga yang melakukan penindakan terhadap tindakan pidana maka kepegawaian dalam KPK tidak terlepas dari adanya Penyidik yang disebut Penyidik Komisi Pemberantasan Korupsi (atau yang selanjutnya disebut Penyidik

\footnotetext{
${ }^{3}$ Martahan Sohuturon, 'DPR Resmi Sahkan Revisi UU KPK' (CNN Indonesia, 17 September 2019) <https://www.cnnindonesia.com/nasional/20190917121442-32-431182/dpr-resmi-sahkanuu-kpk> dikunjungi pada tanggal 30 April 2020.
} 
KPK). Senasib dengan pegawai KPK yang berstatus belum Pegawai ASN, maka Penyidik KPK juga terdapat penyidik yang belum berstatus Pegawai ASN yang mana sering disebut sebagai Penyidik Independen. Penyidik Independen selain membantu lembaga KPK dalam memberantas tindak pidana korupsi di Indonesia juga lebih sering melaksanakan fungsinya sebagai penyidik yang lebih aktif dalam melaksanakan penyidikan tindak pidana korupsi. Berdasarkan UU KPK yang merupakan undang-undang sebelumnya pada Pasal 45 ayat (1) menyebutkan bahwa KPK dapat mengangkat dan memberhentikan Penyidik KPK yang mana menjadi dasar keberadaan adanya penyidik KPK yang merupakan Penyidik Independen. Penyidik Independen merupakan penyidik yang diangkat KPK berdasarkan keberlakuan Undang-Undang KPK sebelum revisi ini yang merupakan penyidik yang belum berstatus Pegawai ASN. Selanjutnya berdasarkan Revisi UU KPK pasal 45 ayat (1) ini mengalami perubahan yang isinya bahwa Penyidik KPK berasal dari kepolisian, kejaksaan, dan pegawai negeri sipil yang diberi wewenang khusus oleh undang-undang, dan Penyelidik KPK. Maka dengan adanya perubahan ini Penyidik KPK yang berstatus bukan Pegawai ASN atau disebut Penyidik Independen tidak disebutkan sehingga tidak memiliki kedudukan hukum. Dan berdasarkan Revisi UU KPK ini, dalam Pasal 69B ayat (1) maka Penyelidik dan Penyidik KPK yang belum berstatus pegawai ASN dapat diangkat menjadi Pegawai ASN sepanjang memenuhi ketentuan perundang-undangan. Oleh karena itu, baik Penyelidik maupun Penyidik KPK sebagai unsur pegawai dalam KPK juga perlu dilakukan konversi status hukumnya dengan Revisi UU KPK ini.

Dengan adanya permasalahan mengenai nasib pegawai KPK yang belum berstatus pegawai ASN mengenai kesempatannya untuk diangkat menjadi pegawai ASN sehingga menjadi penting untuk segera diberikan pemecahan dan solusi untuk mengatasi masalah yang dialami pegawai KPK yang belum berstatus pegawai ASN saat ini sehingga nasibnya menjadi jelas dan tidak tergantung. Selanjutnya pada akhir tahun 2019, 3 (tiga) pegawai KPK yang berstatus belum pegawai ASN memutuskan mengundurkan diri dari KPK. Namun dengan adanya pemberitaan tersebut justru menambah jumlah pegawai 
KPK yang belum berstatus pegawai ASN yang semula 3 (tiga) menjadi 12 (dua belas) orang walaupun dikatakan tidak terkait kejelasan status hukum mereka. Sementara pada awal tahun 2020 adanya pengumuman bahwa akan ada realisasi dari pimpinan KPK saat ini terkait realisasi konversi status pegawai KPK menjadi pegawai ASN tentu akan memberikan akibat hukum kepada pegawai KPK yang belum berstatus pegawai ASN. Hal ini menunjukkan kegentingan dari pembahasan terkait status hukum dari pegawai KPK yang belum berstatus pegawai ASN sehingga jelas kedudukan hukumnya.

Dengan menggunakan Tipe Penelitian doctrinal yaitu research which provides a systematic exposition of the rules governing a particular legal category, analyses the relationship between rules, explain areas of difficulty and perhaps predicts future development. ${ }^{4}$ Maka isu yang akan diteliti membahas mengenai konsep pengangkatan pegawai KPK akibat Revisi UU KPK dalam lingkup normatif.

\section{Status Hukum Penyelidik dan Penyidik KPK, Serta Pegawai KPK Yang Belum Menjadi Pegawai ASN Berdasarkan Hukum Kepegawaian}

Sebelum adanya Revisi UU KPK, baik Penyelidik, Penyidik, maupun Pegawai di lembaga KPK berdasarkan Pasal 24 UU KPK tidak diwajibkan untuk berstatus Pegawai ASN karena belum adanya UU ASN sekaligus Jenis Pegawai yang ditentukan sendiri melalui UU KPK. Sehingga lembaga KPK dengan lebih leluasa dapat memenuhi kebutuhan Penyelidik, Penyidik, maupun Pegawainya dengan mengangkat sejumlah kebutuhan yang disesuaikan dengan anggaran lembaganya. Banyak dari Penyelidik, maupun Penyidik KPK pada masa sebelum Revisi UU KPK justru melaksanakan tugasnya atas panggilan jiwa sehingga pada saat itu sering sekali Penyelidik maupun Penyidik melaksanakan tugas dengan hasil yang baik yaitu menemukan dan mencari bukti-bukti tindak pidana korupsi yang terjadi di lingkungan pemerintahan pusat, pemerintahan daerah, lembaga legislatif, maupun

\footnotetext{
${ }^{4}$ Terry Hutchinson, Researching and Writing in Law (Lawbook Co 2002).[14].
} 
yudisiil. ${ }^{5}$ Sehingga sebelum adanya Revisi UU KPK ini lembaga KPK sebenarnya telah menunjukkan kinerja yang baik dalam mencegah dan memberantas tindak pidana korupsi yang terjadi di Indonesia.

Setelah diberlakukannya Revisi UU KPK, yang berdasarkan penjelasan umumnya pada paragraf 4 (empat) menyebutkan bahwa kinerja KPK dirasakan tidak efektif dan kurang koordinasi antar sesama penegak hukum sehingga harus diperbaiki. Kurangnya koordinasi ini sebelum Revisi UU KPK, merujuk pada UU KPK Pasal 6 huruf a koordinasi tersebut dengan instansi yang berwenang melakukan pemberantasan tindak pidana korupsi yang dalam penjelasan resmi Pasal 6 huruf a disebutkan instansi tersebut adalah Badan Pemeriksa Keuangan (BPK), Badan Pengawas Keuangan dan Pembangunan (BPKP), Komisi Pemeriksa Kekayaan Penyelenggara Negara (KPKPN), serta inspektorat di Kementrian maupun lembaga pemerintah non-Kementrian. Kemudian berdasarkan Pasal 42 UU KPK koordinasi dilakukan KPK dengan orang yang tunduk pada peradilan militer dan umum. Serta berdasarkan Pasal 50 UU KPK dilakukan dengan kepolisian maupun kejaksaan yang kemudian secara khusus dibuat Kesepakatan Bersama Antara Kejaksaan, Kepolisian, dan Komisi Pemberantasan Korupsi Nomor KEP049/A/J.A/03/2012, B/23/III/2012, dan SPJ-39/01/03/2012 Tahun 2012 tentang Optimalisasi Pemberantasan Tindak Pidana Korupsi. Dari Koordinasi-koordinasi dengan para pihak tersebut KPK dinilai kurang sehingga menjadi salah satu alasan perlunya Revisi UU KPK. Selain itu dalam Penjelasan Umum Revisi UU KPK, adanya penyimpangan dan pelanggaran dalam pelaksanaan tugasnya seperti melakukan penyadapan dan tumpang tindih tugas lainnya dengan penegak hukum lainnya merupakan bentuk hasil dari kinerja KPK selama sebelum diberlakukannya Revisi UU KPK. Dengan diberlakukannya Revisi UU KPK ini diharapkan kinerja dari KPK akan lebih baik dibandingkan sebelumnya.

\footnotetext{
${ }^{5}$ Frans Wilmat Muskaman, 'Kinerja Direktorat Penyelidikan, Penyidikan, dan Penuntutan Komisi Pemberantasan Korupsi Dalam Menindaklanjuti Laporan Tindak Pidana Korupsi Periode 2012-2013' (2014) 5 (1) Jurnal Politika.[14].
} 
Setelah berlakunya Revisi UU KPK ini, salah satu yang terpengaruh adalah terkait pemenuhan personal-personal dalam melaksanakan tugas dan fungsi lembaga KPK yang diberikan oleh undang-undang. Dalam Pasal 1 angka 3 Revisi UU KPK menyebutkan bahwa KPK merupakan lembaga negara dalam rumpun eksekutif yang melaksanakan tugas pencegahan dan pemberantasan tindak pidana korupsi sesuai undang-undang ini. Dengan adanya perubahan dari yang sebelumnya lembaga negara eksekutif yang bersifat independen menjadi lembaga negara dalam rumpun eksekutif menunjukkan bahwa adanya restrukturisasi dalam kelembagaan KPK sehingga sesuai dengan struktur lembaga negara lainnya dalam rumpun eksekutif. Terhadap Penyelidik dan Penyidiknya yang sebelumnya dapat berstatus independen dengan Revisi UU KPK ini maka sebagaimana dengan pengaturan dalam penegak hukum lainnya mengenai Penyelidik dan Penyidik maka Penyelidik maupun Penyidik KPK harus merupakan aparatur negara. Dalam Revisi UU KPK ini, pada Pasal 69B ayat (1) menyebutkan bahwa Penyelidik maupun Penyidik KPK yang belum berstatus aparatur sipil negara dalam jangka waktu 2 (dua) tahun sejak diberlakukannya Revisi UU KPK dapat diangkat sebagai Pegawai ASN sepanjang memenuhi peraturan perundang-undangan dan sesuai ayat (2)-nya salah satu syaratnya telah mengikuti dan lulus pendidikan di bidang penyelidikan dan penyidikan sesuai ketentuan peraturan perundang-undangan. Oleh karena itu, baik Penyelidik maupun Penyidik KPK dengan diberlakukannya Revisi UU KPK ini wajib merupakan Pegawai ASN untuk memenuhi syarat personal yang dibutuhkan KPK sebagai lembaga negara dalam rumpun eksekutif.

Selain kepada Penyelidik dan Penyidik dalam lembaga KPK yang diwajibkan berstatus Pegawai ASN, Pegawai KPK sebagai salah satu personal yang dibutuhkan KPK dalam melaksanakan tugas-tugas lainnya juga harus merupakan Pegawai ASN. Hal ini secara eksplisit disebutkan dalam Pasal 1 angka 6 Revisi UU KPK bahwa Pegawai KPK adalah ASN sebagaimana dimaksud dalam peraturan perundangundangan mengenai aparatur sipil negara. Yang kemudian pada Pasal 69C Revisi UU KPK menyebutkan bahwa pegawai KPK yang belum berstatus Pegawai ASN dalam waktu 2 (dua) tahun sejak diberlakukannya Revisi UU KPK dapat diangkat 
menjadi pegawai aparatur sipil negara sesuai peraturan perundang-undangan. Maka Pegawai KPK untuk memenuhi syarat sebagai personal yang dibutuhkan lembaga KPK harus berstatus sebagai Pegawai ASN sebagai pemenuhan atas KPK sebagai lembaga negara dalam rumpun eksekutif.

Selain Penyelidik dan Penyidik, dalam KPK terdapat pegawai yang belum berstatus ASN sehingga pegawai dengan status bukan ASN sejak diberlakukannya Revisi UU KPK secara resmi bukan menjadi pegawai KPK. Sama dengan kebutuhan penyelidik dan penyidik yang terus meningkat, kebutuhan untuk melakukan tugas KPK yang semakin besar dan luas membutuhkan jumlah personal yang lebih banyak sehingga KPK mengangkat pegawai untuk memenuhi kebutuhan tersebut melalui peraturan lembaga KPK berdasarkan ketentuan Pasal 45 ayat (1) UU KPK. Dengan mengangkat pegawai bukan ASN tersebut mempercepat KPK dalam memenuhi kebutuhan personal untuk pelaksanaan tugas lembaga sehingga kepuasaan masyarakat dalam upaya pemberantasan korupsi oleh KPK tetap terjaga. Selain itu, keuntungan KPK mengangkat pegawai bukan ASN mempermudah dalam urusan personalianya dan pengaturan secara internal dalam lembaganya karena terlepas dari aturanaturan yang mengikat pada pegawai ASN seperti mutasi, dan lain sebagainya. Dan oleh Revisi UU KPK yang menyatakan pegawai KPK merupakan ASN dan Pegawai KPK belum ASN dapat diangkat menjadi ASN maka KPK dalam memenuhi kebutuhan pegawainya wajib mengikuti aturan hukum kepegawaian yang ada. Dan oleh karena itu, untuk mengejar kebutuhan pegawai dan menjaga kepuasaan masyarakat akan kinerja lembaga, KPK harus segera memutuskan tindakan dalam mengangkat pegawai belum ASN menjadi ASN atau tindakan lain sehingga lembaga KPK tetap mampu mengimbangi tujuan untuk melakukan pemberantasan korupsi. Masih menjadi permasalahan dalam status pegawai-pegawai KPK yang belum ASN. Dengan Demikian, perbedaan status antara Pegawai sebelum dan setelah diberlakukannya Revisi UU KPK adalah: 


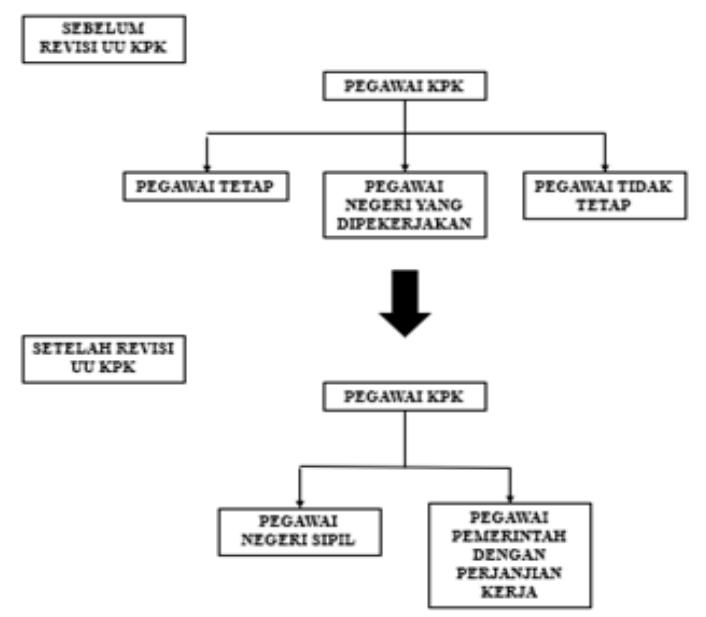

Gambar 1. Bagan Perubahan Pegawai KPK dengan adanya Revisi UU KPK.

Sebelum Revisi UU KPK, berdasarkan Peraturan Komisi Pemberantasan Korupsi Nomor 3 Tahun 2018 tentang Organisasi dan Tata Kerja Komisi Pemberantasan Korupsi (Perkom KPK 3/2018), bagan struktur organisasi KPK adalah:

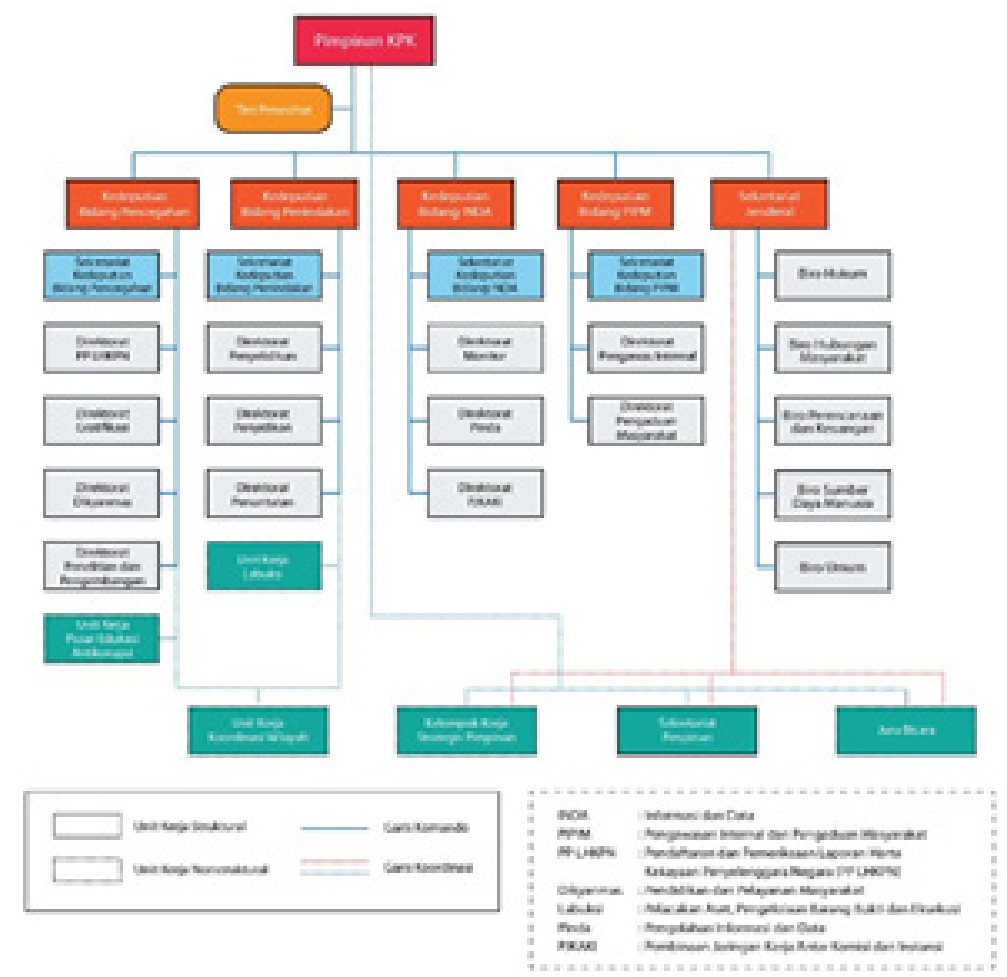

Gambar 2. Bagan Struktur Organisasi KPK

Berdasarkan Pasal 2 ayat (1) Perkom KPK 3/2018 susunan organisasi KPK terdiri atas Pimpinan, Sekretariat Jenderal, Deputi Bidang Pencegahan, 
Deputi Bidang Penindakan, Deputi Bidang Informasi dan Data, Deputi Bidang Pengawasan Internal dan Pengaduan Masyarakat, Tim Penasihat, dan Sekretariat Pimpinan. Pimpinan sebagaimana Pasal 3 ayat (2) Perkom KPK 3/2018 memiliki fungsi-fungsi dan ayat (3) menyebutkan bertanggung jawab kepada publik dan menyampaikan laporannnya kepada Presiden, DPR, dan BPK secara terbuka dan Berkala serta merupakan Pejabat Negara yang merupakan pejabat dilingkungan lembaga negara sebagai alat kelengkapan negara beserta derivatifnya berupa lembaga negara pendukung. Berbeda dengan Pejabat Pemerintahan yang bekerja pada bagian administratif yang membantu pelaksanaan pemerintahan di lingkungan eksekutif. Sehingga kedudukan ini tidak menunujukkan keharusan ditempati oleh ASN. Kemudian Sekretariat Jenderal berdasarkan Pasal 4 ayat (3) Perkom KPK 3/2018 memiliki tugas salah satunya manajemen sumber daya manusia yang dalam hal ini dengan berlakunya Revisi UU KPK maka sumber daya KPK adalah ASN sehingga Sekretariat Jenderal harus ditempati oleh ASN. Berikut biro-biro dibawahnya yaitu Biro Hukum, Biro Hubungan Masyarakat, Biro Perencanaan dan Keuangan, Biro Sumber Daya Manusia, dan Biro Umum. Selanjutnya kedeputian bidang pengawas internal dan pengaduan masyarakat (PIPM) sebagaimana diatur dalam Pasal 47 Perkom KPK 3/2018 yang fungsinya menyiapkan dan melaksanakan kebijakan di bidang pengawasan dan pengaduan masyarakat dalam hal ini dengan adanya Revisi UU KPK tidak menjadi hambatan karena tidak bertentangan dengan fungsi yang dilakukan kedeputian ini sehingga keharusan ditempati ASN bukan merupakan hambatan berikut biro-biro yang dibawahinya. Selanjutnya kedeputian bidang Informasi dan Data sebagaimana diatur dalam Pasal 42 Perkom KPK 3/2018 yang fungsinya terkait pengelolaan sistem, teknologi informasi dan komunikasi di lingkungan KPK sehingga merupakan fungsi internal lembaga yang akibat adanya Revisi UU KPK tidak menjadi hambatan berikut biro-biro yang dibawahinya untuk dikonversikan sebagai ASN karena lingkupnya yang lebih bersifat internal. Kemudian kedeputian bidang pencegahan sebagaimana diatur dalam Pasal 25 Perkom KPK 3/2018 yang fungsinya terkait pemeriksaan dan pendaftaran harta kekayaan penyelenggara negara, gratifikasi, penelitian dan pengembangan dalam 
hal ini kedeputian ini menjadi bagian yang menjalankan fungsi administrasi dalam menerima laporan dari pejabat maupun aparatur negara yang wajib melaporkan harta kekayaannya. Karena fungsi yang lebih bersifat administratif sehingga dengan harusnya Pegawai KPK merupakan ASN tidak menjadi hambatan dalam pelaksanaan tugas. Selanjutnya kedeputian bidang penindakan yang membawahi biro penyelidikan, penyidikan, dan penuntutan. Dalam hal penuntutan, berdasarkan Pasal 51 ayat (3) UU KPK menyebutkan bahwa penuntut adalah Jaksa Penuntut Umum sehingga dengan demikian walaupun berdasarkan Pasal 51 ayat (1) UU KPK KPK mengangkat dan memberhentikan penuntut umum di KPK namun kedudukan penuntut umum diisi oleh Jaksa sehingga wajib merupakan Pegawai Negeri. Terkait Penyelidikan merupakan bagian dari Direktorat Penyelidikan yang berdasarkan UU KPK pasal 43 ayat (1) daingkat dan diberhentikan KPK dalam hal ini sebelum revisi terdapat penyelidik independen yang diangkat oleh KPK yang akibat revisi UU KPK dihapus karena wajib ASN dalam fungsi melakukan penyelidikan dan menjaga independensi KPK seharusnya tidak mewajibkan harus ASN sehingga adanya penyelidik independen menjaga profesionalitas KPK dalam melakukan penyelidikan kepada sesama ASN tanpa melihat jabatan. Selanjutnya biro penyidikan yang dalam UU KPK Pasal 45 ayat (1) diangkat dan diberhentikan KPK dan adanya Penyidik independen namun akibat Revisi UU KPK harus menjadi ASN. Sejalan dengan penyelidik, penyidik seharusnya tidak wajib seluruhnya ASN untuk menjaga profesionalitas KPK dalam melakukan penyidikan kepada ASN lainnya tanpa melihat jabatan. Dengan Demikian maka, Pimpinan KPK, berikut biro penyelidikan, maupun penyidikan seharusnya tidak wajib dari ASN untuk menjamin adanya independensi dan menjaga profesionalitas KPK dalam penindakan korupsi terutama menyangkut ASN.

\section{Hak-Hak Penyelidik dan Penyidik KPK, Serta Pegawai KPK Sebagai Pegawai KPK Sebelum Dan Sesudah Diangkat Menjadi Pegawai ASN}

Dalam Hukum Kepegawaian, Pegawai memiliki kewajiban yang harus dipenuhi dan hak yang didapat sebagai hubungan dalam pelaksanaan dari 
kewajiban yang dilaksanakannya. ${ }^{6}$ Pasal 15 ayat (1) PP Manajemen SDM KPK Jo. Perkom Pegawai KPK bahwa Pegawai KPK berhak atas gaji, tunjangan, dan insentif berdasarkan prestasi kerja tertentu. Gaji Pegawai KPK diatur dalam Perkom Pegawai KPK Pasal 24 ayat (1) didasarkan pada hasil evaluasi jabatan, dan disesuaikan dengan Anggaran Pendaatan dan Belanja Negara (APBN). Selain Gaji, Pegawai KPK berhak mendapat tunjangan sebagaimana Perkom Pegawai KPK yaitu berupa tunjangan transportasi sebagaimana Pasal 33, Asuransi kesehatan dan jiwa sebagaimana Pasal 34, dan tunjangan hari tua sebagaimana Pasal 35. Kemudian selain gaji dan tunjangan Pegawai KPK berhak untuk mendapatkan insentif yang berdasarkan Perkom Pegawai KPK Pasal 36 keputusan pemberian ini ditentukan oleh keputusan pimpinan KPK. Selain gaji, tunjangan dan insentif pekerjaan, Pegawai KPK berhak mendapat keselamatan, keamanan, dan kesehatan kerja sebagaimana Pasal 39 Perkom Pegawai KPK. Selain itu, Pegawai KPK berhak mendapat cuti yaitu cuti tahunan sebagaimana Pasal 41, cuti besar sebagaimana Pasal 42, cuti bersama sebagaimana Pasal 43, cuti melahirkan sebagaimana Pasal 44, dan cuti menjalankan ibadah haji sebagaimana Pasal 45. Selain hal-hal diatas, dalam karirnya Pegawai KPK berhak untuk mendapatkan manajemen karir yang baik yaitu Promosi sebagaimana Pasal 19 ayat (3) huruf (a) Perkom Pegawai KPK, maupun rotasi/mutasi sebagaimana Pasal 19 ayat (3) huruf (b) Perkom Pegawai KPK. Sehingga dengan adanya timbal balik hak dan kewajiban ini baik pemenuhan hak KPK maupun hak pegawainya saling terpenuhi.

Keharusan beralih menjadi ASN maka hak tersebut akan mengalami transisi sebagaimana hak Pegawai ASN. Pegawai ASN memiliki hak yang sebagaimana dalam Pasal 21 UU ASN terbagi menjadi hak Pegawai Negeri Sipil (PNS) maupun hak Pegawai Pemerintah dengan Perjanjian Kerja (PPPK), hak PNS dalam UU ASN adalah memperoleh gaji, tunjangan, dan fasilitas; cuti; jaminan pensiun dan jaminan hari tua; perlindungan; dan pengembangan kompetensi. Sementara hak PPPK dalam Pasal 22 UU ASN adalah memperoleh gaji, dan tunjangan; cuti;

${ }^{6}$ Sri Hartini dan Tedi Sudrajat, Hukum Kepegawaian Di Indonesia Edisi Kedua (Sinar Grafika 2017).[32]. 
perlindungan; dan pengembangan kompetensi. Dilihat secara kedua hak antara PNS dan PPPK tersebut memiliki perbedaan yaitu PPPK memiliki hak yang lebih sedikit daripada PNS dengan tidak dimasukkannya fasilitas, jaminan pensiun dan jaminan hari tua. Dihubungkan dengan hak-hak yang didapat pegawai KPK dalam Perkom Pegawai KPK menunjukkan adanya perbedaan perolehan hak dari Pegawai KPK dan Pegawai ASN yaitu sebagai Pegawai KPK berhak mendapatkan insentif atas pekerjaannya berdasarkan keputusan pimpinan KPK, sementara baik PNS maupun PPPK tidak mengenal istilah insentif dalam pekerjaan selain tunjangan dan gaji. Selain itu, Pegawai KPK berhak mendapatkan tunjangan hari tua saja sementara Pegawai PNS berhak untuk mendapatkan tunjangan hari tua dan tunjangan pensiun dan lain halnya dengan PPPK yang tidak mendapatkan kedua hak tersebut. Maka penjelasan mengenai perbandingan hak sebelum maupun setelah Pegawai KPK menjadi ASN adalah:

\begin{tabular}{|c|c|c|c|c|}
\hline FEOAWAI TETAP & $\begin{array}{l}\text { PEQANEI NEOEKI YANO } \\
\text { DEPEKERJAKAN }\end{array}$ & PEOAWAI TDAX TETAP & PEQAWEI NEOERI SIPII & PPPK \\
\hline 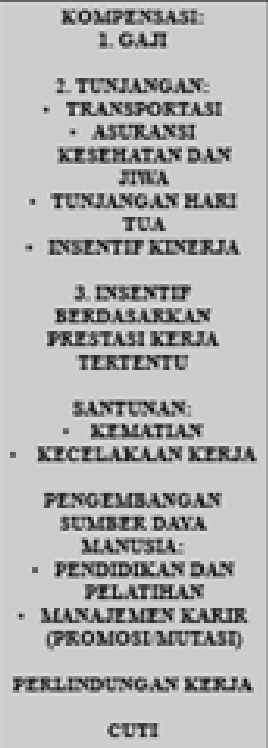 & 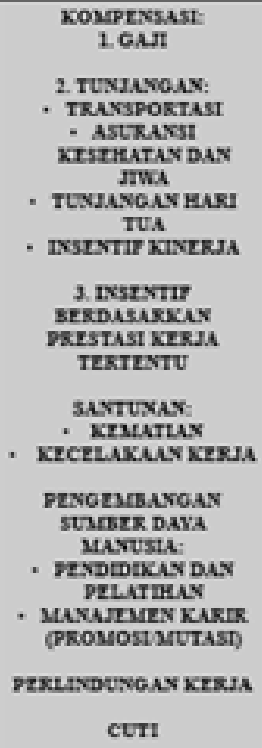 & 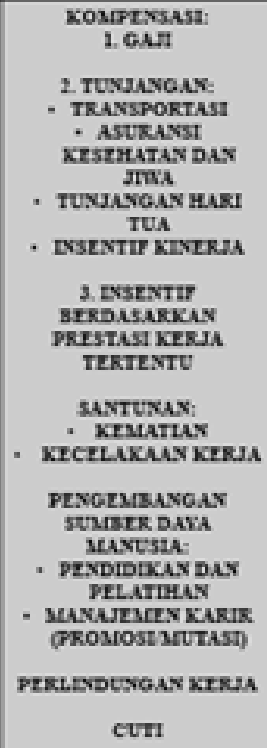 & 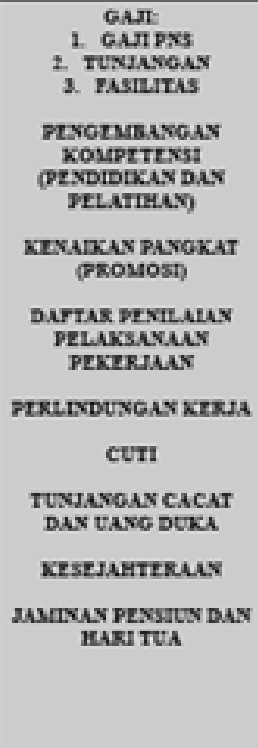 & 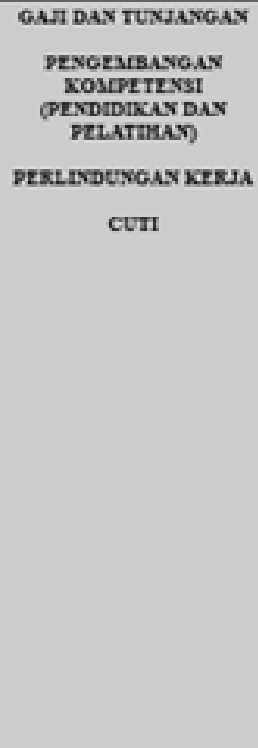 \\
\hline
\end{tabular}

Gambar 3. Perbandingan Hak Pegawai KPK dan Hak Pegawai ASN

Dengan adanya perbedaan dalam pemenuhan hak-hak ini maka apabila KPK melaksanakan konversi Pegawai KPK yang belum berstatus ASN menjadi Pegawai ASN baik PNS dan/atau PPPK maka dalam pemenuhan hak sebagai ASN, KPK harus mengubah Peraturan Komisinya sesuai dengan UU ASN yang 
dengan konversi tersebut akan menguntungkan pegawai yang dapat menjadi ASN PNS karena mendapatkan lebih banyak hak namun akan merugikan ASN PPPK karena hak yang didapatkan jauh lebih sedikit yang tentu merugikan pegawai KPK yang dikonversikan menjadi PPPK.

\section{Wewenang, Prosedur, dan Pelaksanaan Tata Cara Konversi Pengangkatan Penyelidik dan Penyidik KPK, Serta Pegawai KPK Yang Belum Menjadi Pegawai ASN Hingga Menjadi Pegawai ASN}

Kewenangan melakukan pengangkatan merupakan salah satu unsur dalam menentukan keabsahan tindakan pemerintah. Terkait dengan pengangkatan pegawai KPK maka diperlukan pemberian wewenang untuk melakukan tindakan tersebut. Terdapat tiga cara dalam memperoleh wewenang. Cara pertama melalui Atribusi yaitu sebagai cara normal untuk memperoleh wewenang untuk membuat keputusan yang langsung bersumber kepada undang-undang dalam arti materiil. Perolehan wewenang selanjutnya didapat melalui Delegasi yaitu penyerahan wewenang oleh pejabat pemerintahan kepada pihak lain dan wewenang tersebut menjadi tanggung jawab pihak lain tersebut. Cara memperoleh wewenang selanjutnya melalui mandat yaitu suatu pelimpahan wewenang kepada bawahan untuk membuat keputusan atas nama pejabat tun yang memberi mandat sehinggat tanggung jawab tetap pada pemberi mandat. Dalam bahasan mengenai pengangkatan pegawai KPK dilihat sebelum adanya revisi merujuk pada UU KPK Pasal 25 ayat (1) angka 2 menyebutkan wewenang mengangkat dan memberhentikan diberikan kepada Komisi Pemberantasan Korupsi yang disebutkan berdasarkan Pasal 26 ayat (1) UU KPK bahwa Komisi Pemberantasan Korupsi terdiri atas Ketua Komisi Pemberantasan Korupsi dan 4 (empat) orang Wakil Ketua Komisi Pemberantasan Korupsi. Maka berdasarkan UU KPK wewenang pengangkatan pegawai KPK secara atribusi dimiliki oleh Ketua KPK dan 4 (empat) orang Wakil Ketua KPK. Setelah berlakunya Revisi UU KPK Pasal yang menjadi acuan dalam mengangkat dan memberhentikan Pegawai KPK tidak mengalami perubahan sehingga kewenangan setelah berlakunya Revisi UU KPK 
dalam pengangkatan Pegawai KPK tetap dimiliki oleh Ketua KPK dan 4 (empat) orang Wakil Ketua KPK.

Dengan adanya Revisi UU KPK yang kemudian mewajibkan Pegawai Komisi harus berstatus ASN tentu dalam hal ini menimbulkan permasalahan karena Pegawai Komisi tidak seluruhnya merupakan ASN walaupun menjadi Pegawai Tetap maupun Pegawai Tidak Tetap. Merujuk UU ASN Pasal 56 tahapan Perencanaan wajib dilaksanakan Instansi Pemerintah dengan menentuka Jumlah dan Jenis Jabatan PNS dalam waktu 5 (lima) bulan dan ditetapkan oleh Menteri. Kemudian pada tahap pengadaan maka materi ujian penyaringan yaitu pemeriksaan administrasi, tes kompetensi atau akademi, tes psikologi, tes kesehatan, dan wawancara. Yang kemudian oleh Badan Kepegawaian Negara dan Kementrian PAN-RB dengan pertimbangan Menteri Keuangan yang akan memutuskan kandidat yang lolos seleksi. Dalam pelaksanaan proses perencanaan dan pengadaan pegawai KPK melalui Peraturan Komisinya berdasarkan PP Manajemen SDM KPK walaupun memiliki kemiripan secara substansi proses perencanaan maupun penyeleksian, berdasarkan PP Manajemen SDM KPK memiliki perbedaan dimana dalam KPK penentuan proses seleksi merupakan wewenang pimpinan KPK untuk menentukan penerimaan Pegawai Komisi, sementara dalam UU ASN menyaratkan dalam penerimaan Pegawai harus menurut pertimbangan Badan Kepegawaian Negara dan Kementrian PAN-RB dengan pertimbangan Menteri Keuangan. Sehingga, dalam proses Pengadaan Pegawai Komisi setelah Revisi UU KPK Pimpinan KPK tidak berwenang untuk menentukan kandidat yang lolos seleksi untuk menjadi Pegawai Komisi karena seluruh tahapan menjadi kewenangan Badan Kepegawaian Negara dan Kementrian PAN-RB dengan pertimbangan Menteri Keuangan dalam menentukan.

Permasalahan timbul karena untuk melaksanakan pengangkatan Pegawai KPK yang belum ASN tersebut Dalam tahapan ini, hingga pertengahan 2020 belum memiliki perkembangan terkait tata cara konversi Pegawai belum ASN menjadi ASN di KPK. Maka merujuk dalam tata cara konversi Pegawai yang belum ASN menjadi ASN seperti dalam perkembangan berdasarkan PP Manajemen PPPK 
sebagai pelaksanaan UU ASN mengarahkan konversi yang dilakukan kepada Pegawai belum ASN untuk menjadi ASN dengan dikonversi menjadi PPPK Berdasarkan Pasal 99 PP Manajemen PPPK apabila memenuhi persyaratan untuk diangkat sebagai PPPK. Syarat untuk dapat menjadi PPPK berdasarkan Pasal 16 PP Manajemen PPPK yaitu: usia paling rendah 20 (dua puluh) tahun dan paling tinggi 1 (satu) tahun sebelum batas usia tertentu pada jabatan yang akan dilamar sesuai dengan ketentuan peraturan perundang-undangan; tidak pernah dipidana dengan pidana penjara berdasarkan putusan pengadilan yang sudah mempunyai kekuatan hukum tetap karena melakukan tindak pidana dengan pidana penjara 2 (dua) tahun atau lebih; tidak pernah diberhentikan dengan hormat tidak atas permintaan sendiri atau tidak dengan hormat sebagai Pegawai Negeri Sipil, PPPK, Prajurit Tentara Nasional Indonesia, Anggota Kepolisian Negara Republik Indonesia, atau diberhentikan tidak dengan hormat sebagai pegawai swasta; tidak menjadi anggota atau pengurus partai politik atau terlibat politik praktis; memiliki kualifikasi pendidikan sesuai dengan persyaratan jabatan; memiliki kompetensi yang dibuktikan dengan sertifikasi keahlian tertentu yang masih berlaku dari lembaga profesi yang berwenang untuk jabatan yang mempersyaratkan; sehat jasmani dan rohani sesuai dengan persyaratan jabatan yang dilamar; dan persyaratan lain sesuai kebutuhan jabatan yang ditetapkan oleh Pejabat Pembina Kepegawaian (PPK). Dalam hal ini, persyaratan usia PNS umum sebagai ASN berdasarkan Pasal 87 ayat (1) huruf (c) UU ASN jo. Pasal 239 Peraturan Pemerintah Nomor 11 Tahun 2017 tentang Manajemen Pegawai Negeri Sipil (PP Manajemen PNS) adalah 56 Tahun. sementara menurut Pasal 30 Undang-Undang Nomor 2 Tahun 2002 tentang Kepolisian Negara Republik Indonesia (UU POLRI) sebagai institusi yang membutuhkan jabatan salah satunya penyelidik dan penyidik, batas usia adalah 58 Tahun. Dengan demikian, persyaratan dalam melakukan konversi Pegawai Komisi KPK menjadi ASN PPPK tidak terhambat oleh persyaratan menjadi PPPK.

Berdasarkan UU ASN Pasal 99 PPPK dimungkinkan untuk menjadi calon PNS dengan mengikuti semua proses seleksi yang dilaksanakan bagi calon PNS sesuai ketentuan perundang-undangan. Syarat Warga Negara Indonesia menjadi 
PNS yaitu: usia paling rendah 18 (delapan belas) tahun dan paling tinggi 35 (tiga puluh lima) tahun pada saat melamar; tidak pernah dipidana dengan pidana penjara berdasarkan putusan pengadilan yang sudah mempunyai kekuatan hukum tetap karena melakukan tindak pidana dengan pidana penjara 2 (dua) tahun atau lebih; tidak pernah diberhentikan dengan hormat tidak atas permintaan sendiri atau tidak dengan hormat sebagai PNS, prajurit Tentara Nasional Indonesia, anggota Kepolisian Negara Republik Indonesia, atau diberhentikan tidak dengan hormat sebagai pegawai swasta; tidak berkedudukan sebagai calon PNS, PNS, prajurit Tentara Nasional Indonesia, atau anggota Kepolisian Negara Republik Indonesia; tidak menjadi anggota atau pengurus partai politik atau terlibat politik praktis; memiliki kualifikasi pendidikan sesuai dengan persyaratan Jabatan; sehat jasmani dan rohani sesuai dengan persyaratan Jabatan yang dilamar; bersedia ditempatkan di seluruh wilayah Negara Kesatuan Republik Indonesia atau negara lain yang ditentukan oleh Instansi Pemerintah; dan persyaratan lain sesuai kebutuhan Jabatan yang ditetapkan oleh PPK, dan berdasarkan ayat (2) dikecualikan pada jabatan tertentu paling tinggi 40 (empat puluh) tahun. Dari hal tersebut maka semakin mempersempit peluang Penyelidik, Penyidik maupun Pegawai KPK yang apabila dikonversi menjadi ASN PPPK untuk mendapatkan kesempatan menjadi Calon PNS dan mendapatkan hak yang lebih baik. Hal yang menjadi permasalahan utama adalah batas usia tertinggi untuk menjadi PNS adalah 35 (tiga puluh lima) tahun pada saat melamar, dan pada beberapa jabatan paling tinggi 40 (empat puluh) tahun sementara sebagai Pegawai Tetap KPK tidak semua pegawai memiliki usia yang memenuhi syarat calon PNS dan dengan hal ini maka Pegawai Tetap KPK tersebut harus menerima bahwa maksimal dapat diangkat ASN menjadi PPPK. Tentu hal ini semakin merugikan Pegawai Tetap KPK yang harus dikonversi menjadi ASN karena hanya terbatas menjadi PPPK saja. Walaupun dengan dikonversi ini maka Pasal 96 ayat (1) Manajemen PPPK dapat teratasi karena PPK tetap dapat seseorang yang semula hanya Pegawai Tetap KPK yang belum ASN menjadi PPPK yang berdasarkan Pasal tersebut diperbolehkan menduduki jabatan ASN. Dan sejalan dengan itu, maka dengan tenggat waktu 2 (dua) tahun yang ada untuk 
mengkonversi Penyelidik, Penyidik, dan Pegawai yang belum ASN maka PPK juga harus mempersiapkan langkah untuk mempersiapkan Pegawai, Penyelidik, maupun Penyidik yang sudah ASN untuk menggantikan tempat Jabatan ASN yang sebelumnya merupakan Pegawai KPK belum ASN. Namun, kerugian hak yang diterima Pegawai Tetap KPK akibat konversi statusnya menjadi PPPK tidak sebanding dengan kewajiban yang telah dilakukannya selama menjadi Pegawai Tetap KPK sehingga dalam hal ini diperlukan perlindungan hukum untuk Pegawai Tetap KPK yang akan dikonversi menjadi ASN sehingga tetap mendapatkan hak sebagaimana yang seharusnya diterima saat menjadi Pegawai Tetap KPK.

Jabatan berdasarkan Pasal 1 angka (5) PP Manajemen PPPK Jabatan adalah kedudukan yang menunjukkan tugas, tanggung jawab, wewenang, dan hak seseorang pegawai ASN dalam suatu satuan organisasi. Dalam hal ini, jabatan terdiri dari Jabatan Pimpinan Tinggi berdasarkan Pasal 1 angka (6) PP Manajemen PPPK adalah sekelompok jabatan tinggi pada instansi pemerintah yang berdasarkan Pasal 1 angka (7) harus Pegawai ASN. Dan kedua Jabatan Fungsional berdasarkan Pasal 1 angka (8) adalah sekelompok jabatan berisi fungsi dan tugas berkaitan dengan pelayanan fungsional yang berdasarkan keahlian dan keterampilan tertentu. Dari penjelasan kedua jenis jabatan tersebut dihubungkan dengan Pasal 96 ayat (1) PP Manajemen PPPK menunjukkan bahwa Jabatan yang berisi fungsi dan tugas pelayanan fungsional harus merupakan Pegawai ASN sementara KPK berdasarkan Perkom Pegawai KPK Pasal 4 jo. Pasal 5 terdapat Pegawai Tetap yang tidak pasti Pegawai ASN dan Pegawai Tetap ini merupakan Pegawai yang menjalankan fungsi dan Tujuan KPK sebagai Penyelidik, Penyidik, maupun Pegawai dengan tetap mendapat Manajemen Karir berupa Promosi dan Mutasi sebagaimana Pasal 19 Perkom Pegwai KPK. Dengan diberlakukannya Revisi UU KPK ini yang menyatakan Pegawai KPK berstatus ASN sesuai Pasal 1 angka (6) Revisi UU KPK harus merupakan Pegawai ASN sehingga kepada Pegawai Tetap KPK tidak memiliki pilihan lain untuk menerima pengaturan konversi Pasal 69B untuk Penyelidik dan Penyidik, serta Pasal 69C Revisi UU KPK untuk Pegawai KPK dengan menjadi ASN PPPK atau memilih mengundurkan diri sebagai Penyelidik, 
Penyidik, dan Pegawai KPK. Dengan demikian maka kedudukan hukum Pegawai KPK terutama Pegawai Tetap yang menjadi Penyelidik, Penyidik, maupun Pegawai Tetap di KPK berdasarkan Perkom Pegawai KPK menjadi tidak sejalan dengan Revisi UU KPK dan dengan melaksanakan amanat konversi Penyelidik, Penyidik, dan Pegawai KPK menjadi ASN dengan PPPK sebagai salah satunya jalan agar tetap dapat menduduki Jabatan ASN dalam KPK akan merugikan hak dari Penyelidik, Penyidik, dan Pegawai KPK tersebut serta mengamankan PPK dari pelanggaran terhadap aturan Pasal 96 ayat (1) PP Manajemen PPPK.

Sehingga dengan adanya kerugian-kerugian yang akan timbul, maka Pegawai KPK dapat mengajukan upaya perlindungan hukum yang ada untuk memperoleh Kembali hak yang dimilikinya apabila merasa dirugikan. Hukum Administrasi dalam Bagan P. de Haan cs, digambarkan sebagai hubungan yang meliputi upaya penguasa mengatur dan mengendalikan masyarakat, mengatur caracara partisipasi masyarakat dalam proses mengatur dan mengendalikan tersebut, memberikan perlindungan hukum (Rechtsbescherming) serta menerapkan norma pemerintahan yang baik bagi penguasa (Algemene beginselen van behoorlijk bestuur). ${ }^{7}$ Upaya perlindungan hukum merupakan sebuah upaya balik masyarakat yang dirugikan akibat tindakan hukum pemerintah. ${ }^{8}$ Dalam hukum administrasi, tindakan hukum pemerintah tersebut akan dikeluarkan melalui produk hukum yang dikeluarkan pemerintah untuk publik. ${ }^{9}$ Dalam hal melakukan perbuatan hukum tersebut maka pemerintah mengeluarkan sebuah keputusan yang disebut Keputusan Tata Usaha Negara (KTUN). ${ }^{10}$ Pada 2014, seiring perkembangan jaman dikeluarkan aturan hukum mengenai administrasi negara dalam UU Administrasi Pemerintahan yang dalam Pasal 1 angka (7) menyebutkan bahwa KTUN adalah ketetapan tertulis yang dikeluarkan oleh Badan dan/atau Pejabat

\footnotetext{
${ }^{7}$ Philipus M Hadjon, dkk, Pengantar Hukum Administrasi Indonesia (Gadjah Mada University Press 1993).[28].

${ }^{8}$ Bambang Arwanto, 'Perlindungan Hukum Bagi Rakyat Akibat Tindakan Faktual Pemerintah’ (2016) 31(3) Jurnal Yuridika.[362].

9 ibid.

${ }^{10}$ Op. Cit. Philipus M Hadjon, dkk.[135].
} 
Pemerintahan dalam penyelenggaraan pemerintahan yang berdasarkan Pasal 87 UU Administrasi Pemerintahan harus dimaknai sebagai: penetapan tertulis yang juga mencakup tindakan faktual; Keputusan Badan dan/atau Pejabat Tata Usaha Negara di lingkungan eksekutif, legislatif, yudikatif, dan penyelenggaraan negara lainnya; berdasarkan ketentuanperundang-undangan dan AUPB; bersifat final dalam arti lebih luas; keputusan yang berpotensi menimbulkan akibat hukum; dan/ atau keputusan yang berlaku bagi Warga Masyarakat. Yang kemudian berdasarkan Pasal 1 angka (8) UU Administrasi Pemerintahan, melalui ketetapan tersebut dapat dilakukan Tindakan administrasi pemerintahan untuk melakukan perbuatan konkret dalam rangka penyelenggaraan pemerintahannya. Dengan demikian maka sebuah KTUN sebagai dasar melakukan Tindakan administrasi pemerintahan dengan makna yang luas tersebut merupakan suatu tindakan hukum pemerintahan kepada Masyarakat. Sebagai masyarakat yang merasa dirugikan akibat adanya keputusan maupun tindakan pemerintah tersebut dapat menggunakan beberapa jenis perlindungan hukum yang ada sebagaimana yang diatur dalam UU Administrasi Pemerintahan dan peraturan lainnya yang memberikan perlindungan pada masyarakat. Upaya masyarakat pertama yang disediakan dalam UU Administrasi Pemerintahan yaitu Upaya Administratif sebagaimana dalam Pasal 1 angka (16) yaitu proses penyelesaian sengketa yang dilakukan dalam lingkungan Administrasi Pemerintahan sebagai akibat dikeluarkannya Keputusan dan/atau Tindakan yang merugikan. Upaya Administratif Terdapat beberapa alasan upaya administratif dalam penyelesaian sengketa tata usaha negara harus dilakukan. Pertama, konsep pembagian kekuasaan yang bertujuan mencegah tindakan sewenang-wenang dari penguasa dan pemusatan kekuasaan yang apabila permasalahan timbul di lingkungan pemerintahan (eksekutif) maka pemerintah harus memiliki mekanisme penyelesaian sendiri sebelum menyentuh ke bagian kekuasaan lainnya (yudisiil). ${ }^{11}$ Kedua, pemerintah bertugas menyelenggarakan pelayanan masyarakat dan bukan gugatan sehingga penyelesaian melalui badan peradilan merupakan upaya terakhir

\footnotetext{
${ }^{11}$ Hari Sugiharto dan Bagus Oktafian Abrianto, 'Upaya Administratif Sebagai Perlindungan Hukum Bagi Rakyat Dalam Sengketa Tata Usaha Negara’ (2018) 11(1) Arena Hukum.[32].
} 
(ultimum remidium).$^{12}$ Ketiga, dalam menyelesaikan sengketa pemerintah tidak melihat dari aspek hukum saja seperti badan peradilan, namun turut memperhatikan aspek efisiensi dan efektifitas. Dan apabila dilihat dari asas Negara Hukum Pancasila yang mengedepankan kerukunan sebagai inti dari sifat gotong royong menunjukkan upaya penyelesaian sengketa melalui peradilan merupakan upaya terakhir setelah menempuh upaya-upaya lainnya yang salah satunya upaya administratif. ${ }^{13}$

Upaya Administratif berdasarkan Pasal 75 ayat (2) UU Administrasi Pemerintahan terdiri atas: keberatan; dan banding. Dalam mengajukan keberatan sebagaimana Pasal 77 UU Administrasi Pemerintahan, Pejabat Pemerintahan penerima keberatan memiliki tenggat waktu 21 hari kerja sejak diumumkan keputusan dan diselesaikan paling lama 10 hari kerja setelah pengajuan keberatan yang apabila keberatan diterima atau ditolak maka akan diterbitkan keputusan paling lama 5 hari kerja setelah berakhirnya tenggang waktu 10 hari kerja. Apabila keberatan tidak dikabulkan, maka dapat menempuh upaya banding sebagaimana Pasal 78 UU Administrasi Pemerintahan yang diajukan paling lambat 10 hari sejak keputusan upaya keberatan diterima kepada Atasan Pejabat Pemerintahan yang mengeluarkan keputusan keberatan, yang kemudian oleh Pejabat Pemerintahan yang menerima upaya banding tersebut diberikan waktu 10 hari kerja untuk menyelesaikan atau apabila lewat waktu maka dianggap upaya banding dikabulkan dan Pejabat Pemerintahan tetap wajib membuat keputusan paling lambat 5 hari setelah waktu banding berakhir. Dalam UU Administrasi Pemerintahan, upaya administratif merupakan upaya pilihan dengan penggunaan kata "dapat” dalam Pasal 75 ayat (1) UU Administrasi Pemerintahan. Namun merujuk UU ASN Pasal 129 ayat (1) menyatakan bahwa sengketa kepegawaian ASN diselesaikan melalui upaya administratif. Dalam hal ini, UU ASN menjadi lex specialis dari UU Administrasi Pemerintahan yang merupakan lex generalis maka dengan adanya asas lex specialis derogat legi generalis yang mengesampingkan undang-undang yang lebih umum apabila adanya pertentangan norma yang setingkat maka upaya administratif

\footnotetext{
12 ibid.

${ }^{13}$ ibid. [34].
} 
sifatnya menjadi wajib. ${ }^{14}$ Pada tahun 2018, diperkuat dengan dikeluarkannya Peraturan Mahkamah Agung Nomor 6 Tahun 2018 tentang Pedoman Penyelesaian Sengketa Administrasi Pemerintahan Setelah Menempuh Upaya Administratif (Perma 6/2018) pada Pasal 2 ayat (1) menyebutkan bahwa Pengadilan berwenang menerima, memeriksa, memutus dan menyelesaikan sengketa administrasi pemerintahan setelah menempuh upaya administratif. Pengadilan berdasarkan Pasal 1 angka 8 Perma 6/2018 adalah Pengadilan Tata Usaha Negara (PTUN). Berdasarkan Pasal 4 Undang-Undang Nomor 5 Tahun 1986 tentang Peradilan Tata Usaha Negara (UU PTUN) menyebutkan bahwa PTUN berwenang menyelesaikan sengketa TUN. Sengketa TUN dalam Pasal 1 angka (4) UU PTUN adalah sengketa yang timbul dalam bidang TUN antara orang atau badan hukum dengan badan atau pejabat TUN pusat maupun daerah sebagai akibat dikeluarkannya KTUN termasuk sengketa kepegawaian. Maka, keberlakuan Perma 6/2018 mensyaratkan apabila objek sengketa merupakan wewenang peradilan PTUN. Dengan demikian wajib untuk melakukan upaya administrasi terlebih dahulu untuk menyelesaikan permasalahan yang timbul akibat keputusan pejabat TUN apabila ditentukan upaya administrasi memungkinkan untuk dilakukan.

Setelah menempuh upaya administratif berupa keberatan dan banding, apabila kerugian masih dialami maka upaya hukum yang tersedia berdasarkan Perma 6/2018 Pasal 2 ayat (1) yang menyebutkan kewenangan PTUN menyelesaikan sengketa administrasi pemerintahan maka pihak yang masih mengalami kerugian tersebut dapat mengajukan gugatan ke PTUN. ${ }^{15}$ Dengan dasar keputusan banding dari upaya administratif yang telah ditempuh sebelumnya. Yang apabila, keputusan dari PTUN tidak dapat diterima maka dapat mengajukan banding ke PTTUN sebagaimana Pasal 122 UU PTUN. ${ }^{16}$ Dan upaya hukum selanjutnya apabila belum mendapatkan

\footnotetext{
${ }^{14}$ Hari Sugiharto dan Bagus Oktafian Abrianto, 'Perlindungan Hukum Non Yudisial Terhadap Perbuatan Hukum Publik Oleh Pemerintah’ (2018) 33(1) Jurnal Yuridika.[54].

${ }^{15}$ Suparto Wijoyo, Karakteristik Hukum Acara Peradilan Administrasi (Airlangga University Press 2005).[6].

${ }^{16}$ Enrico Simanjuntak, Hukum Acara Peradilan Tata Usaha Negara Transformasi \& Refleksi (Sinar Grafika 2018).[298].
} 
putusan yang dapat diterima dapat mengajukan kasasi kepada Mahkamah Agung sebagaimana Pasal 131 UU PTUN. ${ }^{17}$ Berdasarkan penjelasan tersebut maka terdapat perbedaan alur Pemeriksaan sebelum dan setelah diberlakukannya Perma 6/2018 sebagai berikut:

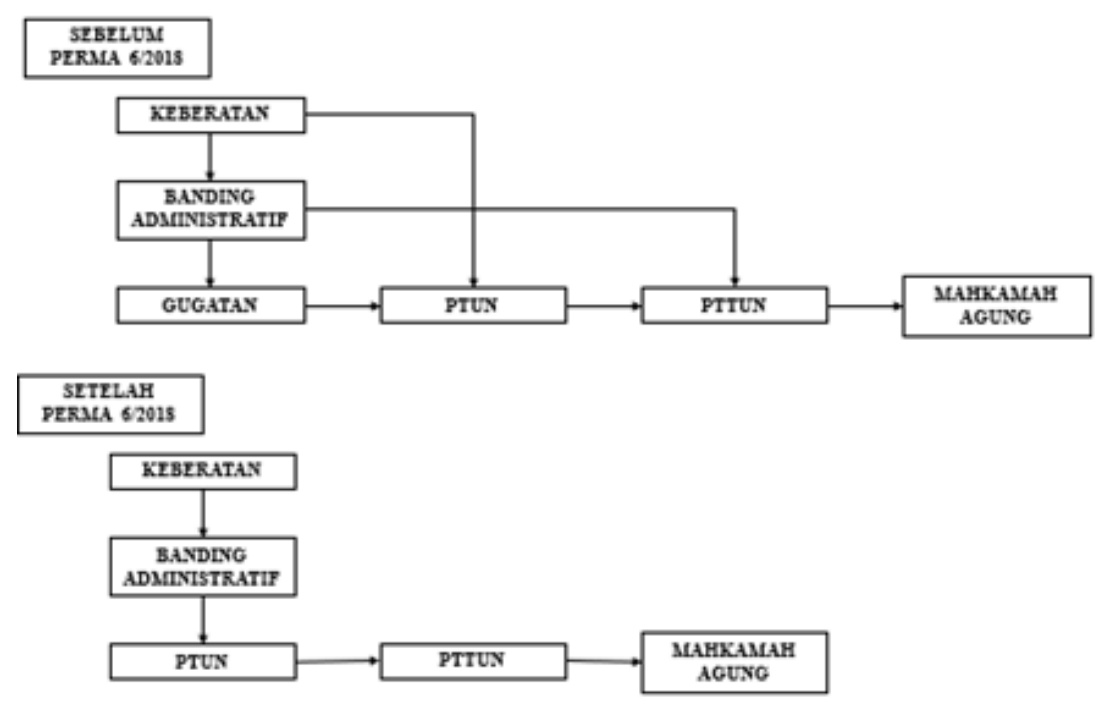

Gambar 4. Perbandingan Alur Sengketa PTUN Sebelum dan Sesudah Perma 6/2018

Upaya untuk menghilangkan kerugian yang dialami selain dapat melalui PTUN juga dapat kepada Pengadilan Negeri apabila kerugian setelah diputusnya gugatan PTUN menguntungkan penggugat namun belum terealisasi. Gugatan kepada pengadilan Negeri dapat mendalilkan kerugian yang dialami sebagaimana Pasal 1365 BW yang menjadi dasar gugatan Perbuatan Melanggar Hukum sehingga menimbulkan kerugian bagi orang lain. ${ }^{18}$ Sehingga apabila gugatan di PTUN atau Pengadilan Tinggi TUN dikabulkan namun kerugian yang dialami belum tertutup maka dapat mengajukan gugatan ke Pengadilan Negeri dengan dasar perbuatan melanggar hukum disertai Keputusan PTUN atau Pengadilan Tinggi TUN yang memperkuat. Namun apabila Putusan PTUN atau Pengadilan Tinggi TUN menolak gugatan tetap dapat mendalilkan kerugian yang dialami sebagai dasar Perbuatan Melanggar Hukum sebagaimana Pasal 1365 BW sehingga dapat berupaya untuk

${ }^{17}$ ibid.[303].

${ }_{18}$ Albert Aries, 'Perbuatan Melawan Hukum dalam Hukum Perdata dan Hukum Pidana' (Hukumonline, 28 Maret 2013) <https:/www.hukumonline.com/klinik/detail/ulasan/lt5142a15699512/ perbuatan-melawan-hukum-dalam-hukum-perdata-dan-hukum-pidana/ $>$ dikunjungi pada 20 Agustus 2020 . 
mengembalikan kerugian yang dialami. Dengan demikian, selain upaya gugatan kepada PTUN atau Pengadilan Tinggi TUN, kerugian yang dialami dapat diajukan gugatan kerugian kepada Pengadilan Negeri yang berwenang untuk menutup kerugian yang dialami. Dengan demikian, selain gugatan diajukan kepada PTUN, kerugian yang dialami dapat diajukan melalui gugatan ke Pengadilan Negeri.

\section{Kesimpulan}

Pengangkatan Penyelidik, Penyidik, Serta Pegawai KPK yang belum berstatus ASN dapat dilaksanakan berdasarkan ketentuan Pasal 99 PP Manajemen PPPK sehingga menjadi Pegawai ASN berstatus PPPK dan tidak antinomi dengan Pasal 96 ayat (1) PP Manajemen PPPK sehingga PPK di KPK tetap bisa memberikan jabatan ASN pada Pegawai PPPK KPK apabila memenuhi persyaratan. Apabila tidak memenuhi maka Pegawai tersebut tidak diangkat menjadi ASN. Dan apabila memenuhi syarat Calon PNS, PPPK tetap dapat mendaftar sebagai calon PNS walaupun dibatasi dengan adanya maksimum usia mendaftar yaitu 35 (tiga puluh lima), atau ditentukan lain maksimal 40 (empat puluh) tahun. Yang dengan adanya batasan tersebut maka, maksimum bagi Pegawai KPK yang diangkat menjadi ASN dan tidak bisa mencalonkan menjadi PNS tetap akan mengalami kerugian hak akibat berkurangnya hak yang diterima oleh Pegawai KPK sebelum diangkat menjadi PPPK. Dan oleh karena itu, maka Pegawai KPK berhak untuk menempuh upaya perlindungan hukum yang telah disediakan perundang-undangan yang ada.

\section{Daftar Bacaan}

\section{Buku}

Enrico Simanjuntak, Hukum Acara Peradilan Tata Usaha Negara Transformasi \& Refleksi (Sinar Grafika 2018).

Philipus M Hadjon, dkk, Pengantar Hukum Administrasi Indonesia (Gadjah Mada University Press 1993).

Sri Hartini dan Tedi Sudrajat, Hukum Kepegawaian Di Indonesia Edisi Kedua (Sinar Grafika 2017). 
Suparto Wijoyo, Karakteristik Hukum Acara Peradilan Administrasi (Airlangga University Press 2005).

Terry Hutchinson, Researching and Writing in Law (Lawbook Co 2002).

\section{Jurnal}

Bambang Arwanto, 'Perlindungan Hukum Bagi Rakyat Akibat Tindakan Faktual Pemerintah' (2016) 31 (3) Jurnal Yuridika.

Frans Wilmat Muskaman, 'Kinerja Direktorat Penyelidikan, Penyidikan, dan Penuntutan Komisi Pemberantasan Korupsi Dalam Menindaklanjuti Laporan Tindak Pidana Korupsi Periode 2012-2013’ (2014) 5 (1) Jurnal Politika.

Hari Sugiharto dan Bagus Oktafian Abrianto, 'Perlindungan Hukum Non Yudisial Terhadap Perbuatan Hukum Publik Oleh Pemerintah' (2018) 33 (1) Jurnal Yuridika.

Hari Sugiharto dan Bagus Oktafian Abrianto, 'Upaya Administratif Sebagai Perlindungan Hukum Bagi Rakyat Dalam Sengketa Tata Usaha Negara' (2018) 11(1) Arena Hukum.

Putu Ayu Mitha Ananda Putri, dan I Gede Yusa, 'Peranan Pegawai Negeri Sipil Dalam Penyelenggaraanpelayanan Terpadu Satu Pintu', (2016) 1(1) Jurnal Universitas Udayana.

\section{Laman}

Albert Aries, 'Perbuatan Melawan Hukum dalam Hukum Perdata dan Hukum Pidana' (Hukumonline, 28 Maret 2013) < https://www.hukumonline.com/ klinik/detail/ulasan/lt5142a15699512/perbuatan-melawan-hukum-dalamhukum-perdata-dan-hukum-pidana/> dikunjungi pada 20 Agustus 2020.

Martahan Sohuturon, 'DPR Resmi Sahkan Revisi UU KPK' (CNN Indonesia, 17 September 2019) <https://www.cnnindonesia.com/ nasional/20190917121442-32-431182/dpr-resmi-sahkan-uu-kpk>dikunjungi pada tanggal 30 April 2020. 
Muhammad Junaidi: Akibat Hukum Keberlakuan...

--halaman ini sengaja dibiarkan kosong-- 